\title{
DIE NASIONALE VLAG EN DIE VLAGHYSING OP 31 MEI 1928
}

\section{INLEIDING}

Reeds twee maande voordat die huidige Nasionale Vlag van die Republiek van Suid-Afrika landswyd en elders in gebruik geneem is, is hierdie vlag op 30 Maart 1928 te Havanna, Kuba, gehys.'

Mnr. Eric H. Louw, toentertyd handelskommissaris van Suid-Afrika in Nieu-York, het 'n vlag laat vervaardig wat tydens die internasionale konferensie insake immigrasie en emigrasie in die Kubaanse hoofstad gehys is. Op dié wyse is ons Nasionale Vlag dus eers in die buiteland ten toon gesprei voordat die eintlike ingebruikneming op eie bodem op 31 Mei 1928 plaasgevind het.

Die vlaghysingsplegtighede op $31 \mathrm{Mei} 1928$ sal as 'n mylpaal in ons vaderlandse geskiedenis bekend bly. Die verkryging van die Nasionale Vlag was 'n belangrike stap in die rigting van staatkundige selfstandigheid, vryheid en onafhanklikheid.

Wanneer die Nasionale Vlag se verskyning in 1928 in dié lig beskou word, dan geld ook in hierdie verband die volgende gedagtes wat deur die beroemde Britse staatsman, Edmund Burke, in die loop van sy bekende „Address to the British Colonies in North America" uitgespreek is :

For liberty is a good to be improved, and not an evil to be lessened. It is not only a private blessing of the first order, but the vital spring and energy of the state itself, which has just so much life and vigour as there is liberty in it.

\section{DIE NASIONALE VLAG}

In artikels 4 en 5 van Wet no. 32, 1961, kortliks bekend as die Grondwet van die Republiek van Suid-Afrika, 1961, is vermeld dat daar 'n Nasionale Vlag van die Republiek van Suid-Afrika is en dat hierdie Vlag bestaan uit drie ewe wye horisontale bane wat van bo na onder oranje, wit en blou is, en waarop voorkom-

a. in die middel van die wit baan, die vlag van die republiek De Oranjevrijstaat wat verticaal en vol oopgesprei afhang; en

b. aan weerskante van en vas teenaan dié vlag

i. die Union Jack, soos dit in 1927 bestaan het, horisontaal en vol oopgesprei in die rigting van die vlagpaal; en

ii. die Vierklcur van De Zuid-Afrikaansche Republiek horisontaal en vol oopgesprei weg van die vlagpaal af.

Hieraan is, met verwysing na die vlae wat in paragrawe a. en b. genoem is, toegevoeg en bepaal dat hierdie vlae ewe groot moet wees en na verhouding dieselfde vorm moet hê as die Nasionale Vlag met die wydte van elkeen van daardie vlae gelyk aan een derde van die wydte van die wit baan op die Nasionale Vlag. Die vlae in paragraaf $b$. genoem, moet ewe ver van die kante van bedoelde wit baan wees. $^{3}$

\section{DIE HISTORIESE AGTERGROND}

In bostaande bewoording is die Nasionale Vlag van die Republiek van Suid-Afrika in ons Grondwet omskryf. Die bekende Suid-Afrikaanse heraldikus dr. C. Pama 
het die geskiedenis van ons huidige Nasionale Vlag nagegaan en nadruk gelê op die feit dat die oranje-wit-blou vlag die getuie van die begin van die Suid-Afrikaanse nasie was. ${ }^{4}$

In die loop van die agtiende eeu het die rooi-wit-blou vlag eersgenoemde al hoe meer verdring. ${ }^{5}$

Nadat die Britse bestuur sy intrede in ons land gedoen het, is die bestaande Hollands-Afrikaanse vlagtradisie in die Boererepublieke voortgesit, terwyl die Britse tradisie, gesimboliseer in die vorm van die Union Jack, sy intrede aan die Kaap en in Natal gedoen het.

Gebaseer op hierdie vlagtradisies, wat die oorsprong, die ontwikkelingsgang en die onderlinge verband in laasgenoemde verband simboliseer, het die toenmalige Unievlag soos omskryf in die Unie Nasionaliteit en Vlaewet van 1927 (wet no. 40, 1927) tot stand gekom.

Van hierdie vlag, ons Nasionale Vlag, getuig dr. Pama onder meer :

Dit is voldoende om te sê dat, uit die maalstroom van gedagtes en menige voorstelle, daar tenslotte die gelukkigste oplossing gekom het: die Van Riebeeckvlag wat aan die wieg van Suid-Afrika gestaan het.

Op die wit baan in die hart van hierdie vlag is die drie ander vlae geplaas as ' $n$ teken dat, sedert die tyd van Van Riebeeck, daar verdere ontwikkeling plaasgevind het.'

Hierdie verdere ontwikkeling het gelei tot die staatkundige eenwording in $1910 \mathrm{en}$, ruim 'n halwe eeu later, tot die beliggaming van die begeerte om algehele staatkundige vryheid en onafhanklikheid te verkry, in die totstandkoming van die Republiek van Suid-Afrika.

\section{SIMBOOL VAN 'N NASIE}

Die Nasionale Vlag is, aldus prof. dr. F. J. Wessels, die simbool van die staat. Na binne is die Nasionale Vlag die uiterlike simbool vir die nasionale bewussyn van die volk. Na buite is dit die onderskeidende simbool van die staat in sy verkeer met ander state.

Dan is daar die digter C. J. Langenhoven wat die Nasionale Vlag in sy „Vlaglied” besing het as 'n seël van vryheid en reg, 'n kosbare erfenis wat van geslag tot geslag soos 'n kleinood oorgedra moet word. Dieselfde digter het die Nasionale Vlag as 'n grondbrief beskryf wat op gesag van die Allerhoogste uitgegee is . . . . . '

En wanneer ons vir 'n oomblik ons Nasionale Vlag met ons Nasionale Volkslied verenig en aan die Suid-Afrikaanse Weermag se indrukwekkende vlaghys- en vlagstrykseremonies $^{10}$ dink, dan besef elkeen die dieper betekenis van die volgende sinvolle woorde wat soos 'n gebed klink :

Ons sal antwoord op jou roepstem,

Ons sal offer wat jy vra;

Ons sal lewe, ons sal sterwe;

Ons vir jou Suid-Afrika.
At thy call we shall not falter;

Firm and steadfast we shall stand;

At thy will to live or perish;

O South Africa, dear land.

Waar die Nasionale Vlag dan die simbool van 'n nasie is, is dit vanselfsprekend dat daar, behalwe 'n voorskrif met betrekking tot die ontwerp van hierdie vlag, ook 'n groot aantal ander reëls neergelê is om die waardigheid van hierdie simbool hoog te hou. 
In dié verband is die volgende voorskrif, ontleen aan die S.A. Weermag se handleiding Salueer en Eerbewys, ${ }^{14}$ ongetwyfeld een van die belangrikste. Dit lui, met as opskrif „Waardigheid van die Nasionale Vlag”, soos volg :

Personeel wat verantwoordelik is vir die voer wan die Nasionale Vlag, moet toesien dat gepaste eerbied en seremonieël by die hantering van die vlag aan die dag gelê word, en dat die waardigheid van die staat, soos versimboliseer in die voer van die Nasionale Vlag, hoog gehou word."

\section{EERBIED TEENOOR DIE NASIONALE VLAG}

Uit bogenoemde voorskrif blyk dat daar, teenoor die Nasionale Vlag, eerbied betoon moet word om te voorkom dat die waardigheid van die Staat en die nasie, wat dit simboliseer, nie in die gedrang kom nie. 'n Stel voorskrifte, behorende tot die vlagprotokol, waarvan bogenoemde slegs een is, is in verskeie lande neergelê en gee antwoord op die vraag wat wel met 'n vlag kan en mag gedoen word en wat nie veroorloof is nie. ${ }^{12}$

Dr. C. Pama verklaar onder meer dat dit nie gebruiklik is om uitvoerprodukte van 'n afbeelding van die Nasionale Vlag te voorsien nie, om op die wyse aan te dui dat die produkte van Suid-Afrika afkomstig is. Afbeeldings van vlae op bekers, koppies, tafeldoekies en dergelike, wat later vuiltgesmeer kan word, is, volgens dieselfde skrywer, heeltemal ongewens. ${ }^{13}$ Die Nasionale Vlag mag nie oor 'n motorkap, die dak, langs die sykante van of agter op 'n voertuig, 'n trein of 'n skip bevestig word nie. ${ }^{14}$

In die reeds aangehaalde S.A.W.-publikasie Salueer en Eerbewys ${ }^{15}$ verskyn onder andere die volgende voorskrifte :

a. Tye wanneer die Nasionale Vlag gewapper word :

Die Nasionale Vlag sal daagliks vanaf 0800-uur tot sonsondergang op vlagstasies gewapper word met dien verstande dat :

a. Die wapper van die Nasionale Vlag ingekort mag word tot normale werksure by vlagstasies war omstandighede dit vereis.

b. Oorsese kantore van die Republiek mag die tye wanneer die Nasionale Vlag gewapper mag word varieer, om aan te pas by lokale gebruike en omstandighede.

b. Hysing van die Nasionale Vlag :

Die Nasionale Vlag moet vyf minute voor die gespesifiseerde tyd gehys word terwyl dit nog opgerol is. Op die gespesifiseerde tyd moet die vlag gebreek word.

By geleenthede waar ' $n$ aantal vlae vertoon word, moet die Nasionale Vlag eerste gehys en gebreek word; daarna word ander vlae gebreek.

c. Stryking van die Nasionale Vlag :

Op die uur van sonsondergang, of op enige vasgestelde tyd, moet die Nasionale Vlag stadig gestryk word. By geleenthede waar 'n aantal vlae gevoer word, word die nasionale vlag laaste gestryk.

d. Onder die opskrif Die voer van die Nasionale Vlag op Seremoniële of herdenkingsdae is vermeld :

Die volgende dae is aangewys as herdenkingsdae en op hierdie dae moet die Nasionale Vlag vir seremoniële gebruik gevoer word. 

a. Van Riebeeckdag : 6 April
b. Republiekdag : $31 \mathrm{Mei}$

Afgesien van die dae hierbo aangedui, mag die vlag vir seremoniële geleenthede gevoer word op instruksie van die Departement van die Eerste Minister.

e. Die Nasionale Vlag halfmas gevoer :

Die Nasionale Vlag mag slegs in opdrag van die Departement van die Eerste Minister halfmas gevoer word.

Wanneer die Nasionale Vlag halfmas gevoer word, word dit gehys tot bo, ontplooi en dan stadig gestryk totdat die middel van die vlag halfpad tussen die kloot en die onderent van die vlagpaal is. Wanneer die vlag met sonsondergang of op enige vasgestelde tyd gestryk word, moet die vlag eers stadig tot bo gehys en dan op die normale manier gestryk word.

Nota: 1. Gedurende periodes van rou, waar die Nasionale Vlag halfmas gevoer word, moet daar geen ander vlag gevoer word nie.

2. Geen vlaghys- of vlagstrykseremonie sal plaasvind by vlagstasies gedurende ' $n$ rouperiode nie. ${ }^{16}$

f. Begrafnisse :

By militêre begrafnisse moet die kis met die Nasionale Vlag gedrapeer word, met die broeking van die vlag bo-aan en die wapperkant aan die voetenent. Die oranjestreep moet regs van die kis wees, van die kop na die voetenent van die kis gesien."

Uit bostaande voorskrifte volg op 'n oortuigende wyse dat die owerheid van die Republiek van Suid-Afrika tereg van die gedagte uitgaan dat, as gevolg van sy simboliek en die besondere assosiasies, die Nasionale Vlag met eerbied behandel moet word.

\section{DIE EERSTE-NASIONALE VLAGHYSING (1928)}

Op 31 Mei 1928 is, oor die lengte en breedte van die Unie van Suid-Afrika, die Nasionale Vlag, toentertyd bekend as die Unievlag, vir die eerste keer gehys. In Kaapstad is sowel die Unievlag as die Union Jack deur die toenmalige Goewerneurgeneraal, die graaf van Athlone, gehys, terwyl die twee vlae op Pretoria deur die goewerneur-generaal se gade, H.K.H. Prinses Alice, voor die Uniegebou ontvou is.

Ter herinnering aan hierdie gebeurtenis is daar, op 'n paar voet afstand van die plek waar die Unievlag voor die Uniegebou gehys is, 'n plaveiklip wat die hedendaagse besoeker na dié merkwaardige dag terugvoer. In dié verband het J. D. Bodel 'n paar jaar gelede verklaar :

Since 1928, the South African flag has come to be so common-place as to be unremarked. Yet its creation was attended by acrimony and dispute..$^{18}$

En in sy aangrypende gedig, vol van verskillende stemmings en dikwels ontroerende gedagtes, het die digter Toon van den Heever" die staatsman-filosoof die volgende gedagtes in die mond gelê : 
Vier met my, burgers, want ons stryd is oor,

Die vaandelvraag is eindelik opgelos.

Die stryd was bitter en die tweedrag kwaai.

Ons vlag was soos 'n skepie wat daar swalk

Op die ruwe bare van die oseaan.

En net soos by die hawehoof genaak,

Word hy deur woeste winde teruggeslaan.

Goddank! Daar is 'n end aan die awery!

Kom tree ons nou soos manne moedig voort

En ban uit ons geled're broedertwis

En streef na die heil van ons diepbedroefde land . . . . .

En aan die slot van dieselfde gedig verklaar die moeder van die Vrouemonument onder meer :

\section{Gaan onbeklad die eeue langs daarheen. ${ }^{20}$}

in Kaapstad het, soos reeds vermeld is, die Goewerneur-generaal die nuwe Nasionale Vlag ontvou, die toeskouers toegespreek en daarna genl. J. C. Smuts en Eerste Minister genl. J. B. M. Hertzog aan die woord gestel.

In die loop van sy toespraak het die Goewerneur-generaal onder meer van die Nasionale Vlag verklaar:

It follows that a flag must be a living thing. It must be born, it must be kept alive, and it must grow. The past may give it birth, but the past alone will not sustain it to live, to grow it must draw ever new inspiration, new life blood. So to-day our new flag is born - born of great traditions, the emblems of which are emblazoned upon it, but more than that. Today, to everyone in the country without distinction of race or creed, the life of that flag is entrusted. From the very moment when it first flutters above us it will demand, in order that it may live, a living contribution from each one of us - the fire of true endeavour, the inspiration of great deeds, the sustaining food of high example. ${ }^{21}$

'n Dag voordat hierdie verrigting plaasgevind het, is ten tye van sonsondergang, die Union Jack, wat gedurende 'n tydperk van 122 jaar onafgebroke oor die Kasteel gewapper het, vir die laaste keer gestryk. Aan 'n persverslag is die volgende beskrywing van dié gebeurtenis ontleen :

At a few minutes before six a soldier mounted the Leerdam bastion and approached the flagstaff. He paused a moment, standing silhouetted against the rosy glow in the sky. As he did so a breeze suddenly sprang up and the flag, which had hitherto hung lifelessly against the flagpole, spread its folds wide and then fluttered slowly down . . . . .

Om elfuur die volgende dag het kanonne van die bolwerke van dieselfde Kasteel gebulder; voor die historiese parlementsgebou het die generale saluut weerklink, die Goewerneur-generaal het op 'n knoppie gedruk en gelyktydig het die Nasionale Vlag en die Union Jack begin ontvou en het die skare begin juig . . . . . .

In Johannesburg is die twee vlae op goewermentsgeboue gehys en in Londen het 'n groot skare aanskou hoe prins Arthur van Connaught, in sy hoedanigheid as verteenwoordiger van koning George $\mathrm{V}$, betreklik kort voor elfuur op Trafalgarplein aangekom het. Terwyl trompetgeskal weerklink het, het die Nasionale Vlag van die Unie van Suid-Afrika, saam met die Union Jack, in die hartjie van die toenmalige Britse wêreldryk begin wapper en het "Die Stem van Suid-Afrika" weerklink. 'n Nuwe vlag het sy buiging op Suid-Afrikahuis gemaak . . . . . . 


\section{DIE VERRIGTINGS TE PRETORIA}

Hier volg allereers die verslag van 'n ooggetuie van die plegtigheid, met militêre eerbewys, voor die gedenkwaardige Uniegebou. Vervolgens word aandag gewy aan die militêre verrigtings.

a. Ooggetuieverslag. ${ }^{22}$

Her Royal Highness Princess Alice arrived in Pretoria this morning by train from Cape Town very quietly and with little ceremony. A special coach for the Royal party was linked up to the back of the train.

The Bishop of Pretoria (the Right Rev. Neville Talbot) and Miss Talbot, with whom Her Royal Highness will stay during the short time she is in the capital, were on the platform to meet her, also the Administrator (the Hon. J. H. Hofmeyr), the Commissioner of Police (Colonel Sir Theodore Truter), Major Jackson, of the S.A. Police, and Captain Beyers.

The Princess remained in her coach until 10.30, thereafter motoring up to the Union Buildings for the unfurling ceremony. Captain Fielden, A.D.C., and Mrs. Birch Reynardson were in attendance.

At 11.15 a.m. the flags of the Union were unfurled at the Union Buildings. There was an enormous crowd of many thousands of people to witness the ceremony. The use of amplifiers enabled a considerable portion of the vast assembly to hear the speeches.

\section{THE PRINCESS SPEAKS}

People began to gather early. At 10 o'clock there was music by the excellent band of the S.A. Police, and a special choir, directed by Mr. John Connell. Percisely at $10.45 \mathrm{Her}$ Royal Highness Princess Alice and suite arrived, and the National Anthem was played. On a small platform decorated in red were those taking the leading parts in the ceremony.

The Bishop of Pretoria offered prayer, and thereafter prayer was offered by the Moderator of the Dutch Reformed Church, the Right Rev. Paul Nel.

His Honour the Administrator was the first speaker, and before and during his speech aeroplanes hovered overhead. Mr. Hofmeyr spoke first in Dutch and then in English.

Her Royal Highness, who was received with cheers said: "At this selfsame hour my husband, the Governor General, is to unfurl the two flags of the Union in Capetown, and before doing so he will speak to the people so assembled. And as I have the privilege to perform the same ceremony in Pretoria, I am sure you will feel it most fitting that I should now read you his address."

The Governor-General's speech was greeted with loud applause.

\section{GUNS AND BUGLES}

At the conclusion of the speech read by Her Royal Highness the unfurling ceremony took place. It is a perfectly gorgeous day, with scarcely any evidence of a breeze. By a mechanical device the Princess was able to hoist the two flags simultaneously. Slowly they travelled up the two masts, and a few seconids after they had reached the summit both broke simultaneously and a happy little gust of wind served to make them flutter gaily. There was a burst of applause, and then the thunder of the 21 guns and the sound of bugles. 
At the call of the Administrator, three very hearty cheers were given for Her Royal Highness, many of those present at this joyous moment no doubt remembering afresh the significance of the deep black in which our gracious Princess was dressed.

His Honour the Administrator then asked Her Royal Highness to accept as a memento of the occasion-a small casket containing a miniature of the flag. This little ceremony evoked an outburst of applause.

Mr. Patrick Duncan next addressed the gathering, and was followed by Mr. Tielman Roos, who spoke in both languages.

After Mr. Roos had spoken, two verses were sung from "Die Stem van Suid-Afrika" and the National Anthem, after which the troops marched past. Military and police played their part notably in to-day's ceremonial, .........

b. Die militêre aandeel in die Pretoriase verrigtings.

Op 23 Mei 1928 het luitenant-kolonel A. H. M. Nussey, C.B.E., D.T.D., D.S.O., bevelvoerder nr. 5 Militêre Distrik, 'n order in verband met die vlaghysingseremonie uitgereik.

Op 7 Junie 1928 het die voorsitter van die Vlagseremonie-komitee, Administrateur Jan H. Hofmeyr, namens sy komitee die volgende bedankingsbrief aan die Unieverdedigingsmag gerig wat deur Brigadier-generaal $\mathrm{H}$. S. Wakefield, in sy hoedanigheid as Adjudant-generaal, verder onder die aandag van 'n aantal geadresseerdes gebring is.

Hier volg die tekste van die besondere order en die bedankingsbrief :

\section{SPECIAL DISTRICT ORDER}

ISSUED BY

LIEUTENANT COLONEL A. H. M. NUSSEY, C.B.E., D.T.D., D.S.O., OFFICER COMMANDING NO. 5 MILITARY DISTRICT.

District Headquarters,

Potgieter Street,

Pretoria.

May 23rd, 1928.

Ceremony of hoisting the Flags of the Union of South Africa, May 31st, 1928.

1. The Ceremony of hoisting the Flags of the Union of South Africa will take place at the Union Buildings, Pretoria, on May 31st 1928 at 1030 hours.

2. The unfurling of the Flags will be done by H.R.H., Princess Alice.

3. Troops. Detachments from the following Units will parade :-

S.A. Field Artillery,

S.A. Air Force,

Defence Headquarters,

XII Infantry (Pretoria Regiment),

S.A. Corps of Signals, 
S.A. Police,

Pretoria Commando,

Cadets,

also

Boys Scouts,

S.A. Naval Brigade,

S.A. Nursing Service and V.A.Ds.

Girl Guides.

All Troops must be in position at 1015 hours

4. $\quad$ Order of Dress.

Permanent Force : Review Order "A".

A.C.F. Units Officers : $\quad$ Review Order

Field Service Dress with Medals and

Decorations.

D.R.A. Officers :

Service Dress with Medals.

Service Dress with Medals and

Decorations.

NOTE : Swords will not be drawn, except by Officers of the Guard of Honour.

5. Transport. Units from Roberts Heights will make their own arrangements about transport.

The Cadets from Daspoort and Pretoria North will be provided with a railway warrant, and a Tram from the Central Station to the Union Buildings and back.

Other Units will not be provided with transport.

6. Route. The Detachments from the S.A. Permanent Force, A.C.F. Units, Police and Commando will enter the parade ground from the West.

Members of the Nursing Service, V.A.Ds. and Girl Guides will also enter from the West.

Cadets, Boys Scouts, Naval Brigade will enter by the eastern gate in Church Street, march through the grounds, up the eastern steps, and enter the upper road from the East.

The Band of the S.A. Police will take up a position between the steps, being the main entrance to the amphitheatre. Western Side.

An Ambulance Section will be stationed behind the Troops on the

Note: A rough sketch of the parade ground is attached for reference.

7. Markers: A Marker from each Unit attending this parade must report to S/S Liebenberg on the grounds at 0930 hours.

Captain G. H. Kruger, D.T.D. who will be in attendance on the O.C., and who will be assisted by members of this Staff, will direct all Units to their positions.

8. Arms. Only the Guard of Honour will be armed. All other troops will parade with side arms only.

9. Guard of Honour : The XIIth Infantry will furnish a Guard of Honour of 3 Officers and 100 Rank and File, and their position will be opposite the platform as shown on the sketch, with 6 Buglers also drawn from that Unit, on the Right flank of the Guard. 
10. Salute of 21 Guns. The 1st Battery S.A. Field Artillery will fire the salute.

11. March Past: At the conclusion of the Ceremony all Units will march past the Flags, the Artillery leading. The Cadets, Boys Scouts and Naval Brigade will march along the northern pavement, pass behind the Guard of Honour, wheel to the left and then follow on.

The March will continue in an easterly direction until the top of the Tramway route be reached. From that point the Permanent Force Units will march to their conveyances and dismiss under their own arrangements.

The XIIth Infantry will march to and dismiss on the Market Square.

All other Units will dismiss under their own arrangements, but not on either the upper or lower roads (tramway route).

The Police Band will play during the March Past from its position between the steps of the main entrance.

The Guard of Honour will move off after all troops are clear, and join the rest of the Detachment of their Unit.

12. Programme: The official programme, and all words of command are also attached for reference.

Major,

for OFFICER COMMANDING: NO. 5 MILITARY DISTRICT.

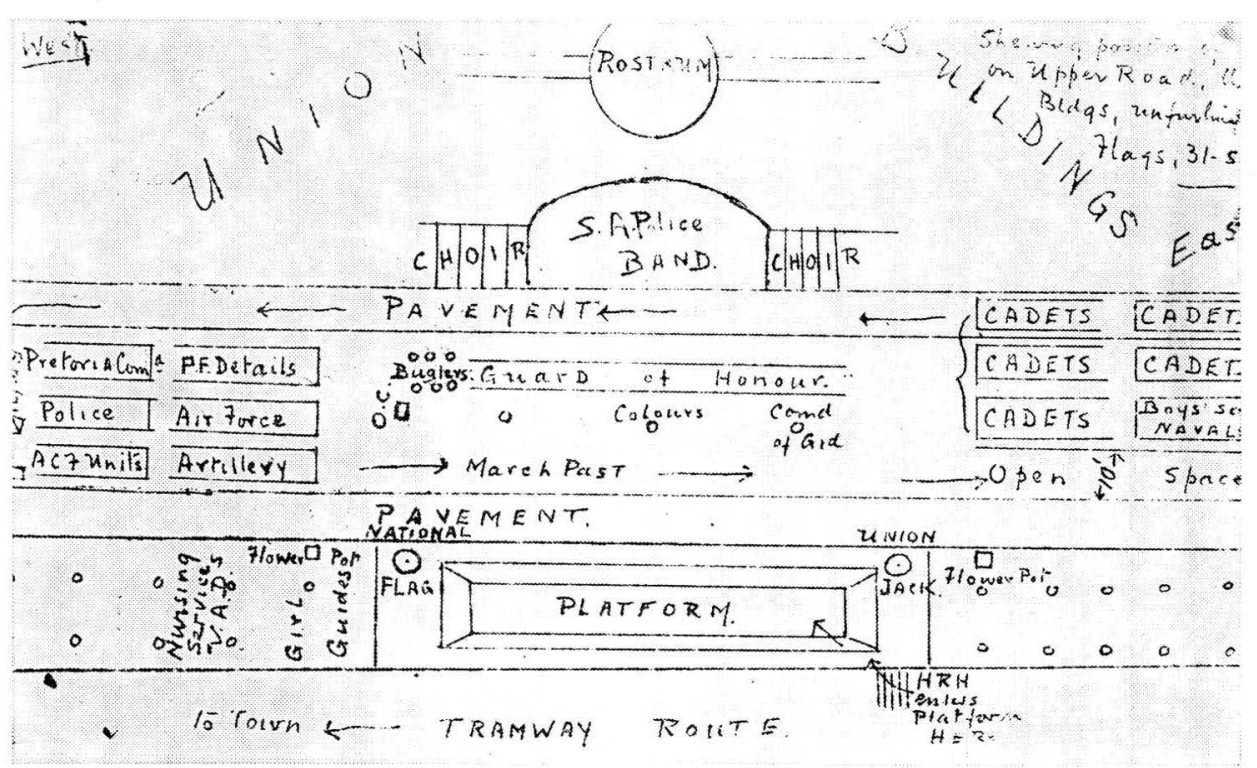

Sketch of the parade ground.

Photograph : Phatographic Section, C. DOC. S., S.A. Defence Force.

Skets van die paradeterrein. 


\section{$P R O G R A M M E$}

1015 hours : All Units in position.

C.O. will give command :-

"Parade Attention."

"Officers to the front - march."

Officers will fall-in in front of leading Units and take up their dressing from the right.

C.O. will give command :-

"Parade, - stand at ease."

1030 hours : Music by Band and Choir.

1045 hours : $\quad$ Arrival of H.R.H. Princess Alice.

C.O. gives the command :

"Parade Attention."

The Commander of the Guard will then give the command :"Slope Arms."

So soon as H.R.H. appears on the Platform, the Commander of the Guard will give the command :-

"Royal Salute."

"Present Arms."

Band playing "God save the King" (six bars).

- Officers saluting.

Guard Commander will then give the commands :-

"Slope Arms",

"Order Arms."

C.O. gives command :-

"Parade - Stand at ease."

Presentation of Bouquet to H.R.H.

Prayer by Rt. Rev. the Bishop of Pretoria.

Prayer by the Moderator, Dutch Reformed Church.

Address by His Hon., the Administrator, Mr. Hofmeyr.

1059 hours : His Hon. the Administrator announces H.R.H. Princess Alice.

C.O. gives command :-

"Parade attention."

The Guard Commander gives the command :-

"Slope Arms."

1100 hours : H.R.H. Princess Alice breaks Flags.

The Guard Commander gives the command :-

"Present Arms."

Bugles sound "General Salute."

First gun of salute is fired on signal.

Commander of Guard gives command :-

"Slope Arms."

"Order Arms."

Troops will remain at "Attention" until the completion of the Artillery Salute.

C.O. gives command :-

"Parade - Stand at ease."

The Hon. Patrick Duncan, K.C., C.M.G., M.L.A., will now speak, followed by the Hon. T. J. de V. Roos, K.G., M.L.A. (Minister of Justice). 
At the conclusion of these speeches, the Choir will sing two verses each from :-

"Die Stem van Suid-Afrika" and

"God save the King."

Before "God save the King" is sung, the C.O. will give the command :-

"Parade - Attention."

Officers will salute during the first verse only - The Guard will not present arms.

Upon the departure of H.R.H. Princess Alice, the Guard Commander will give command :-

"Royal Salue."

"Present Arms."

The Police Band will now play "God save the King," (six bars), Oficers saluting.

So soon as H.R.H. has left the Platform, the Commander of the Guard will give the order :-

"Slope Arms."

at which position the Guard will remain until the March Past is completed.

The C.O. will now give the command :-

"Officers - take post."

"Parade will march past in column of fours - Artillery leading." Unit Commanders (commencing with the Artillery) will then give the command :-

"Artillery (or as the case may be) will advance in column of fours."

Upon reaching the National Flag, the command

"Eyes right"

until past the Union Jack, when the command

"Eyes front"

will be given, and Units will proceed in the Order.

Pretoria.

7 Jun 1928

THE QUARTERMASTER GENERAL.

THE DIRECTOR OF AIR SERVICES.

THE DIRECTOR OF MEDICAL SERVICES.

THE CAMP COMMANDANT, ROBERTS HEIGHTS.

THE COMMANDANT, S.R. MILITARY COLLEGE.

THE O.C., 1st BATTERY S.A.F.A.

THE O.C., 2nd BATTERY S.A.F.A.

THE O.C. SECTION 3rd BATTERY S.A.F.A.

Ceremony of Hoisting the Flag of the Union of South Africa

I beg to subjoin for your information and necessary action, a copy of a letter from the Chairman, Flag Ceremony Committee :- 
"Dear Sir,

I shall be glad if you will kindly convey the thanks of the Flag Ceremony Committee to all the Military Units which took part in the Ceremony at the Union Buildings on Union Day.

The participation in the Ceremony of detachments from the various Units contributed very largely towards making the occasion a most impressive one and reflects great credit on all concerned.

I shall be glad if you will also kindly cause the thanks of the Committee to be conveyed to the Boy Scouts, S.A. Naval Brigade, S.A. Nursing Service, V.A.D.'s and Girl Guides.

I would like to add in conclusion that the smooth working of the programme points to careful staff arrangements having been made."

Yours faithfully,

(sgd.) Jan H. Hofmeyr.

CHAIRMAN,

FLAG CEREMONY, COMMITTEE.

(sgd.) H. S. Wakefield.

Brigadier-General,

ADJUDANT GENERAL. U.D.F.

\section{AANTEKENINGE}

1. C. Pama, Die Unievlag. Sy oorsprong, betekenis en gebruik, (Kaapstad, 1957), p. 30.

2. Burke's speeches and letters on American Affairs, (London, 1924), pp. 221-222.

3. Wet no. 32, 1961, artikels 4, 5 .

4. C. Pama, t.a.p.

5. Ibid., p. 3. In 1652 het hierdie vlag reeds, aldus dieselfde skrywer, 'n veelbewoë geskiedenis agter die rug gehad. Dié vlag het tydens die vryheidstryd tussen die Nederlanders en Spanje ontstaan.

6. Ibid., pp. 26-27.

7. C. Pama, t.a.p.

8. Foto-Beeld, bylae tot Die Beeld, 26.5.1968. Sien ook : R. Gerard, C. Pama, t.a.p., p. 37; Flags over South Africa, (Pretoria, 1952), p. 19; I. O. Evans, Flags, (London-Melbourne, 1970), onder „Foreword".

9. C. Pama, t.a.p., p. 1.

10. Seremoniële Handboek vir die Suid-Afrikaanse Weermag (1971), Ceremonial Manual for the South African Defence Force (1971).

11. Uitgawe 1971, p. 401 e.v., paragraaf 12.

12. Sien o.m. K. Sierksema, Vlaggen. Symbool. Traditie. Protocol, (Bussum, 1963), p. 40 e.v.

13. C. Pama, t.a.p., pp. 37-38.

14. K. Sierksema, t.a.p., p. 41 (V.S.A.-voorskrif, 1942).

15. Pp. 401-402.

16. Hierna volg: Vertoning van die Nasionale Vlag in geboue of op verhoë.

17. Hierna volg: Algemeen (p. 403).

18. Argiefnuus, Mei 1968, p. 38 (,The South African Flag”).

19. Eugene en ander Gedigte, (Pretoria, 1951), p. 76 e.v.

Komdt. W. Otto het die skrywer se aandag op die gedig "Die vlaghysing" gevestig.

20. Ibid., p. 86 .

21. Hierdie en die volgende besonderhede is ontleen aan The Star, Johannesburg, 31.5.1928.

22. Dieselfde koerant. Opskrif : At the Union Buildings. Princess Alice unfurls flags.
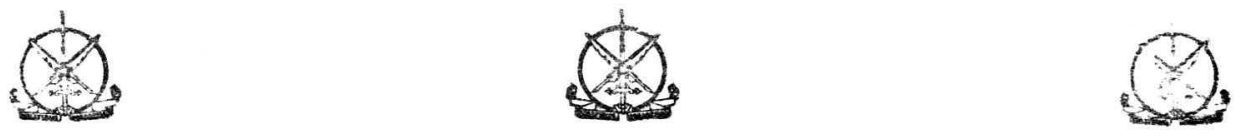


\section{SUMMARY}

In this brief contribution the importance of the first hoisting in this country of its National Flag on 31 May 1928 is stressed.

In addition, and by reference to the provisions of the Republic of South Africa Constitution Act, 1961 (Act No. 32 of 1961), the existing National Flag is described.

After a short resumé of the coming into being of the National Flag, there follows some thoughts in regard to the National Flag as a national symbol. As such, the National Flag engenders the deepest respect from both uniformed personnel and civilians. A number of explanatory examples are mentioned to illustrate this aspect in a military context.

The last portion of the contribution relates to the actual flag hoisting ceremonies on 31 May 1928. Stress is laid, in particular, on the military contribution to the ceremonial flag hoisting which took place in front of the Union Buildings, Pretoria on May 1928.

The writer continually stresses the fact that citizens of the Republic of South Africa can never demonstrate sufficient respect for their Naional Flag. 


\section{Publications of the Central Documentation Service, S.A.D.F.}

At present, the Central Documentation Service, S.A.D.F. (formerly M.H.A.S.) has the following two publication series:

a. Separate publications, each dealing with one specific subject.

b. The military historical magazine Militaria.

As Publication No. 1 of the first-mentioned series appeared:

The Fortification of Pretoria. Fort Klapperkop - Yesterday and Today, by Comdt. Jan Ploeger, M.A., M.Ed., D.Phil., Acad., assisted by Maj. H. J. Botha, M.A., T.H.E.D.

This publication is illustrated and thoroughly documented and can be obtained from The Government Printer, Pretoria. Prices: R2,30 (local, post-free), R2,90 (foreign, post-free).

\section{MILITARIA:}

Since Volume 2 (1970) the price of Militaria has been R1,35 whilst the annual subscription for Militaria (6 editions) is R8,00 (local, post-free) and R10,00 (foreign, post-free).

Militaria is obtainable from: The Government Printer, Private Bag 85, Pretoria, Republic of South Africa.

\section{Contents:}

Annual 1 (1969): (Obtainable from the Government Printer at the prices indicated).

Capt. E. Jonker, B.A. (Hons.): Die Militêr-Historiese en Argivale Dienste van die Departement van Verdediging (1/1, pp. 26 , price $40 \mathrm{c})$.

Comdt. H. J. Botha, M.A., T.H.E.D.: Die moord op Derdepoort, 25 November 1899. Nie-blankes in oorlogsdiens (1/2, pp. 98, price R1,05).

Comdt. J. Ploeger, M.A., M.Ed., D.Phil., Acad.: Hoofstukke uit die voor-en vroee geskiedenis van die S.A.W. (1/3) pp. 87, price $\mathrm{R} 1,00$ ).

Comdt. J. Ploeger, M.A., M.Ed., D.Phil., Acad.: Op Brandwag - Drie eeue militêre geskiedenis van Suid-Afrika (1/4 pp. 47 , price $60 \mathrm{c})$.

Comdt. J. Ploeger, M.A., M.Ed., D.Phil., Acad.: Suid-Afrikaanse Verdedigingsskemas (1887-1914) (1/5, pp. 96, price R1,05).

Annual 2 (1970) (1971):

Col. H. J. Botha, M.A., T.H.E.D.: Historiese oorsig van die ontstaan van die militêre lugvaart en die selfstandige lugmagte (2/1, pp. 1-13).

Comdt. J. Ploeger, M.A., M.Ed., D.Phil., Acad.: Die opleiding van ons eerste vlieëniers (2/1, pp. 14-35).

Comdt. J. Ploeger, M.A., M.Ed., D.Phil., Acad.: Die "Zuid-Afrikaanse Vliegeniers Korps" : Vliegtuie en personeel vir en in Suidwes, 1914-1915 (2/1, pp. 36-55).

Comdt. J. Ploeger, M.A., M.Ed., D.Phil., Acad.: 26 Eskader R.F.C. (2/1, pp. 68-87).

Comdt. J. Ploeger, M.A., M.Ed., D.Phil., Acad.: South African Air Force Nominal Roll of Officers, Air W.O.'s, Air N.C.O.'s and Airmen (2/1, pp. 88-94).

Comdt. J. Ploeger, M.A., M.Ed., D.Phil., Acad.:

Twee (?) Duitse vliegtuie van Duala (2/1, pp. 95-109).

Brief Notes referring to five S.A.A.F. Squadrons (1939-1945) by Capt. P. J. Albertse, B.A., Dip. A., Sgt. P. J. Brink, Miss C. Bergh, B.A., L.S.T.D., and Mrs. L. Glatthaar, conclude this illustrated 128 page publication.

Comdt. J. Ploeger, M.A., M.Ed., D.Phil., Acad.: Besonderhede aangaande 'n aantal geboue op die terrein van die huidige Verdedigingshoofkwartier, Potgieterstraat, Pretoria (2/2, pp. 1-25).

Comdt. J. Ploeger, M.A., M.Ed., D.Phil., Acad.: Die Kasteel "De Goede Hoop" (1921-1923) : Die verhaal van 'n reddingsdaad (2/2, pp. 27-46).

Comdt. J. Ploeger, M.A., M.Ed., D.Phil., Acad.: Die militêre boukuns in die Nederlande en sy eertydse kolonies (15001800) $(2 / 2$, pp. 49-59). 
Comdt. J. Ploeger, M.A., M.Ed., D.Phil., Acad.: Military architecture in the Netherlands and her former colonies (15001800) $(2 / 2$, pp. 61-67).

Comdt. G. J. Geyer, B.A.(P.E.), B.A.(P.E.)Hons., T.H.E.D., M.A.(P.E.): Liggaamlike opleiding in die Unie-Verdedigingsmag (1912-1946) (2/3, pp. 140).

Kol. H. J. Botha, M.A., T.H.O.D. en

komdt. J. Ploeger, M.A., M.Ed., D.Phil., Akad.: Die Duitse Aandeel in die Militêre Geskiedenis van Suid-Afrika en Suidwes-Afrika. (2/4, pp. 1-25).

Col. H. J. Botha, M.A., T.H.E.D. and

Comdt. J. Ploeger, M.A., M.Ed., D.Phil., Acad.:

The German Contribution to the Military History of South Africa and South-West Africa. (2/4, pp. 26-50).

Oberst H. J. Botha, M.A., T.H.E.D. und

Oberstleutnant J. Ploeger, M.A., M.Ed., D.Phil., Acad.:

Der deutsche Anteil an der Militärgeschichte Süd- und Südwestafrikas, 2/4, pp. 51-72).

Comdt. J. Ploeger, M.A., M.Ed., D.Phil., Acad.: The South African Field Post and Telegraph Corps 1914-1915. (2/5, pp. 76).

J. W. North, Research Assistant Union War Histories: South African Postal Services (1940-1946). (2/6, pp. 1-51). A Short History of the Base Post Office Durban (1940-1946). (2/6, pp. 52-68).

Comdt. J. Ploeger, M.A., M.Ed., D.Phil., Acad.: Notes on the 6th South African Armoured Division Postal Unit. (2/6, pp. 69-73).

Annual 3 (1972) (1973):

Admiral Hugo Hendrik Biermann, S.S.A., O.B.E., Commandant-General S.A. Defence Force. (3/1, p. iii).

Comdt. J. Ploeger, M.A., M.Ed., D.Phil., Acad.:

Uit die voorgeskiedenis van die Suid-Afrikaanse Vloot:

Die ontstaan van die Suid-Afrikaanse Seediens. (3/1, pp. 1-80).

First Annual Report on the Board of Control S.A.T.S.

"General Botha". Year ending 14th July, 1922. (3/1, pp. 82-100).

Corpl. N. Gomm:

From the ship's log of H.M.S.A.S. Imhoff. (3/1, pp. 102-110).

Comdt. J. Ploeger, M.A., M.Ed., D.Phil., Acad.: Suid-Afrika en die Imperiale Generale Staf-gedagte. (3/2, pp. 1-16).

Comdt. J. Ploeger, M.A., M.Ed., D.Phil., Acad.: Die Imperiale militêre beleid ten opsigte van Suid-Afrika (1908-1910). (3/2 pp. 19-29).

Comdt. J. Ploeger, M.A., M.Ed., D.Phil., Acad. Duitse amptelike korrespondensie in verband met die verdediging van en fortebou in die Zuid-Afrikaansche Republiek. (3/2, pp. 30-39).

Comdt. Jan Ploeger, M.A., M.Ed., D.Phil., Acad., and

Capt. F. J. Jacobs, B.A. (Hons.), U.E.D.: Victoria Cross Awards. (3/2, pp. 40-83).

E. Jonker, M.A., U.E.D.: Ontstaan en ontwikkeling van die Transvaalse Verdedigingsmag: Transvaal Volunteers (3/3, pp. 1-112).

Col. J. Ploeger, M.A., M.Ed., D.Phil., Acad. :

Nederlandse "Springbokke" en die Brigade. 'n Bydrae tot die geskiedenis van die "Koninklijke Nederlandsche Brigade 'Prinses Irene,". (3/4, pp. 1-103). 